\title{
In these pages ...
}

What is the latest news in the world of psychoanalysis? New discoveries, sensational insights? Perhaps. This issue, however, is dedicated to the experiences and ideas inspired by Sándor Ferenczi's insights. It brings to light select unearthed treasures of our psychoanalytical heritage; this is not to bring us back to out-dated views left behind in the historical development, but to remind us that much of our psychoanalytic inheritance consists of ideas bursting forth from the close and rich interactions of a group of smart, enthusiastic people—sometimes flamboyantly so. ${ }^{1}$

Psychoanalysis, similar to any newly established science, has been striving for its place in the general system of science since its early days. At first, hope prevailed that models of other sciences could be applied to building a robust, unassailable and respectable structure based on natural (empirical) sciences (as Freud has hoped) and so avoid woolly philosophizing. Other thinkers supposed that psychoanalysis could become a specific part of psychology or even a "general psychology". Some pioneers, among them Ferenczi, proposed, however, that psychoanalysis should be considered as an innovative genuine science. ${ }^{2}$ It would be patient-centred and based on the discourse and other manifestations in the "analytic situation" (as Ferenczi and Rank called it), that is, in the daily therapeutic experiences as well as in other observational situations, like that of babies and young children (Haynal, 2002). Ferenczi thus gave us the courage of being and remaining analysts without searching for "help" in other domains of knowledge, staying nevertheless in a dialogue with them (see Appelbaum, 2013). Not servant but partner of other sciences. With time, the new structure of ideas became more formalized but still allowed continuous inclusion of new thoughts, clues and hints. Ferenczi gave a foremost example of listening to the various expressions of the unconscious, thus stimulating our work through the present time. As in a previous issue of this Journal, on reflections evaluating Rank's work in hindsight (Dupont, 2012), this publication on Ferenczi's oeuvre also inspires a critical look at some important parts of our inheritance. Most notably, it highlights our sensitivity and difficulties concerning trauma, and more generally our emotional, erotic and sexual life.

Something undeniable has also been taking place since the 1980s: a renewed appreciation of the impact of trauma, hitherto undervalued by 
many, in spite of its painful burden for countless individuals, both patients and clinicians. A search of the subject of trauma, in the database of the PEP yields hundreds of entries. But interestingly, the number of English language trauma entries from 1971 to the mid 1980s is only a fraction of the entries in the years that followed. It is only in 1980 that the American Psychiatric Association for the first time included the diagnosis of Post Traumatic Stress Disorder in its DSM III, shining light on a greatly neglected topic. Coincidentally, Sándor Ferenczi's (1932) Clinical Diary was first published in 1985 in French and then in 1988 in English. The availability of that long-suppressed work gave the psychoanalytic community a stimulatingly fresh dynamic perspective on trauma, and reconnected many practitioners with a most important part of our psychoanalytic legacy.

Peter Rudnytsky's article may serve as an introduction, giving a convincing example of a psychoanalytical methodology close to Ferenczi's thinking. It shows a way to read our history associatively and interpretatively. It leads us to the other contributions of this issue, written around various aspects of the experience of trauma and the theory it inspires.

In a similar vein, the work of Galina Hristeva shows the lesser-known themes of Ferenczi's work, about the links of pleasure with its physiological bedrock, such as joy and satisfaction in our bodies. The sources of the libido identified in the perspective of the then fashionable ideas of "philosophers of life" (Lebensphilosophen, like Schopenhauer and Nietzsche) are presented as a counterweight to the dimension of trauma.

Trauma (the central subject of investigation in this issue), and the theory built around it imply the use of the analyst's main instrument: his or her sensitivity. The empathy used in the first place through introjection and identification. The analyst works through his or her positive and negative feelings in a struggle for understanding. Some of the present contributions about trauma attempt to build bridges from Ferenczi's teachings to more recent authors. This is well demonstrated by Judy Eekhoff's centration on the clinical experience with these often-difficult patients. Following the path opened by Ferenczi, she strives to integrate it with other contemporary thinkers, and like our other authors, she definitively stays outside any sectarian tendency.

The defensive attitude towards the traumatized patient, which Carlo Bonomi points to in his paper, underlines the importance of the analyst's negative and positive influences. Moreover, the confrontation with the traumatized person's fragmented mental life and narcissistic split stresses the importance of the emotional working through in extreme cases with bits of mutual analysis. These considerations may lead us to a better understanding of Freud's reactions on the Acropolis, as Bonomi shows it, and to the hypothesis that the Viennese founder of psychoanalysis tended 
to abandon not only the concept of trauma as a theory but also the traumatized person, such as Ferenczi. Evidently, the attitude, influence and understanding of the analyst's own functioning greatly affect the analytic process.

This brings us to two very touching articles, one by Giuditta Ceragioli and the other by Endre Koritar, regarding the concept of elasticity and emotional exchanges. Giuditta Ceragioli gives us a sensitive commentary about a correspondence of her young patient with the writer Primo Levi, a highly traumatized survivor of the Holocaust. Endre Koritar's account of a clinical case is-evidently a different historical weight-one of persevering, fine understanding and courageous identification with and exploration of the tragic consequences of early traumatization. His work shows convincingly that psychoanalysts can help traumatized persons. These two authors round up this Special Issue, which inspires us to evolve and broaden the understanding of our patients.

All these contributions increase our knowledge of our rich past and complex present. The papers we are publishing in this Special Issue, and the one to follow, are a selection from presentations at the highly successful 8th International Sándor Ferenczi Conference, "Faces of Trauma", which took place in Budapest from May 31 to June 3, 2012, and was organized by Judit Mészáros, the President of the Sándor Ferenczi Society, and her team.

\section{NOTES}

1. Well illustrated in the recently published volume of Ferenczi \& Jones (1911-1933): Letters.

2. In parenthesis, the question of innovative genuine science, is one of the elements in the fight about lay psychoanalysis, with Freud and Ferenczi on one side, and Jones and others on the other: for Ferenczi it was desirable to have non-medical analysts with humanistic studies in their training (see Freud and Ferenczi, 1920-1933).

André E. Haynal

Guest Editor

\section{REFERENCES}

Appelbaum, J. (Ed.) (2013). Psychoanalysis and philosophy: Nurturing dialogues. Special Issue, American Journal of Psychoanalysis, 73(2).

Dupont, J. (Ed.) (2012). Recognizing Otto Rank, an innovator. Special Issue, American Journal of Psychoanalysis, 72(4).

Ferenczi, S. (1932). The clinical diary of Sándor Ferenczi. J. Dupont (Ed.), M. Balint \& N. Z. Jackson (Trans.). Cambridge, MA: Harvard University Press 1988. 
Ferenczi, S. \& Jones, E. (1911-1933). Letters. F. Eros, J. Szekacs-Weisz \& K. Robinson (Eds.). London: Karnac 2013.

Freud, S. \& Ferenczi, S. (1920-1933). The correspondence of Sigmund Freud and Sándor Ferenczi. Volume 3: 1920-1933. E. Falzeder \& E. Brabant (Eds.) with the collaboration of P. Giampieri-Deutsch. Cambridge, MA \& London, UK: The Belknap Press of Harvard University Press 2000.

Haynal, A. (2002). Disappearing and reviving. Sándor Ferenczi in the history of psychoanalysis. London: Karnac.

DOI:10.1057/ajp.2013.28 